\title{
The Feasible Textbook for Algebra Learning
}

\author{
Esti Harini ${ }^{1}$, Irham Taufiq ${ }^{2}$, Fitria Sulistyowati ${ }^{3}$, Denik Agustito ${ }^{4}$ \\ \{esti@ustjogja.ac.id ${ }^{1}$, irham.taufiq@ustjogja.ac.id ${ }^{2}$, \\ fitria.sulistyowati@ustjogja.ac.id ${ }^{3}$,rafaelagustito@ustjogja.ac.id ${ }^{4}$ \} \\ Mathematics Education of Universitas Sarjanawiyata Tamansiswa, Yogyakarta, Indonesia 1234
}

\begin{abstract}
The aim of this study has produced a textbook for algebra learning. This study was used Research and Development (R\&D) method but restricted to textbook validity with steps: (1) exploration study; (2) initial product develop-ment; and (3) expert validity and product revision. The subject of this study were college students of the mathematics education department at Sarjanawiyata Tamansiswa University in the 2018-2019 academic year. Material expert and textbook expert who validate are lecturers of Mathematics Education Depart-ment with a minimum academic position as Expert Assistant. The mean score for the material is 4.60 which is categorized very well, while the mean score for the textbook is 4.65 which is categorized very well too. Based on the validation and product revision, it can be concluded that the algebra learning textbook that has been designed is feasible.
\end{abstract}

Keywords: Algebra, Textbook, Research and Development, Validity Test.

\section{Introduction}

Universal Algebra is something everyone ought to know about, though nobody should specialize in it [1]. Therefore, algebra lessons are required for students in mathematics education department, Sarjanawiyata Tamansiswa University (UST). Algebra equation is one of the discussions in the algebra lesson. There are many methods used in solving problems related to algebraic equations, but students still have difficulty in choosing what method should be used to solve algebraic problems. In mathematics, teachers are asked to enact approaches that often differ greatly from their own experiences of mathematics instruction [2] and that require a deeper knowledge of mathematics than many teachers have [3], [4], [5]. So, the teachers must create new innovations in learning which make students have no difficulty in mathematics, especially in algebra lessons.

Teaching instruments are very important in learning that is as a representation of teacher explanation in class to achieve the expected competencies. Teaching instruments as instructional media in learning are useful for: (1) uniformity in the learning process; (2) the instructional process becomes more interesting; (3) the learning process becomes more interactive; (4) learning time can be reduced; (5) the quality of learning can be improved; (6) the learning process can occur anywhere and anytime; (7) the positive attitude of students towards learning discussions and the learning process itself can be improved, and (8) the role of teachers can change in a more positive direction [6]. In fact, as many as $40 \%$ of all freshmen in four-year colleges and universities require some form of developmental education 
[7]. Based on this, the development of teaching instruments is a new innovation that can be applied in algebraic learning.

Algebra learning in mathematics education department of UST is still using conventional books or teaching instruments in Indonesian and English which contains a summary of the discussions, sample questions, and exercises but the strategy of organizing and delivering content in the teaching instrument is not good structured. This makes students lazy to read it, let alone learn it. This is suspected to be one of the causes of students' incomprehension in studying algebra lessons. As a result, the learning motivation of student has decreased. This makes the teacher try to solve the problem. One of them is by developing teaching instruments such as textbooks.

The good textbook to be used in algebra learning which is oriented to competencies. The textbook has several components, such as: (1) review of discussions; (2) introduction; (3) learning activities; (4) exercises; (5) exercise clues; (6) summary; (7) formative tests; (8) formative test answer and feedback [8]. The textbook that designed without competency oriented and not contain those components, is certainly useless for students.

Basically, a teacher must make improvements to the paradigm, perspective, thinking, attitudes, habits, professionalism, and teaching behaviour. These improvements are one of the innovations to designed teaching instruments that will have an impact on the continuity learning activities of students so that they do not feel bored. Therefore, the development of textbooks for algebra learning is very important to improve the learning activities of students and also as an effort to improve the quality of the teacher.

\section{Methods}

\subsection{Research Methods}

This study was used Research and Development (R\&D) method with Borg and Gall development model consisting of 5 steps: exploration study, initial product development, expert validation, and product revision, finite regional test and product revision, main regional test and final product. But, in this study restricted to textbook validity with steps: (1) exploration study; (2) initial product development; and (3) expert validity and product revision [9]. Data collection techniques used are questionnaires which given to material experts and textbook experts.

\subsection{Subject and Place of Research}

The subject of this study is the $1^{\text {st }}$ semester college students of the mathematics education department at UST in the 2018-2019 academic year.

\section{Result and Discussion}

The results of this study are learning instruments in the form of textbooks for college students in the Mathematics Education Department, UST who attend Algebra lessons. The textbook was developed is a teaching instrument prepared by the teacher to flesh out students' knowledge. The title of the textbook is Algebra Textbook. The discussions in textbooks are written based on basic competencies. There are equality-inequality linear and quadratic, equality and inequality of exponents, logarithms and irrationals, rational function, sequence, and 
series scheme. The discussions of the textbook that was chosen based on the results of an exploratory study which included literature and competence review, and analysis of student characteristics.

\subsection{Textbook Overview}

Textbooks that have been designed, better than other books because this textbook was explained the basic concepts and how to solve algebraic problems. In addition, there are any proof of fast formulas and is completed with international and non-routine exercises. One of the differences of the textbook that developed with conventional textbooks related to the basic concepts of algebra can be seen in Fig. 1 .

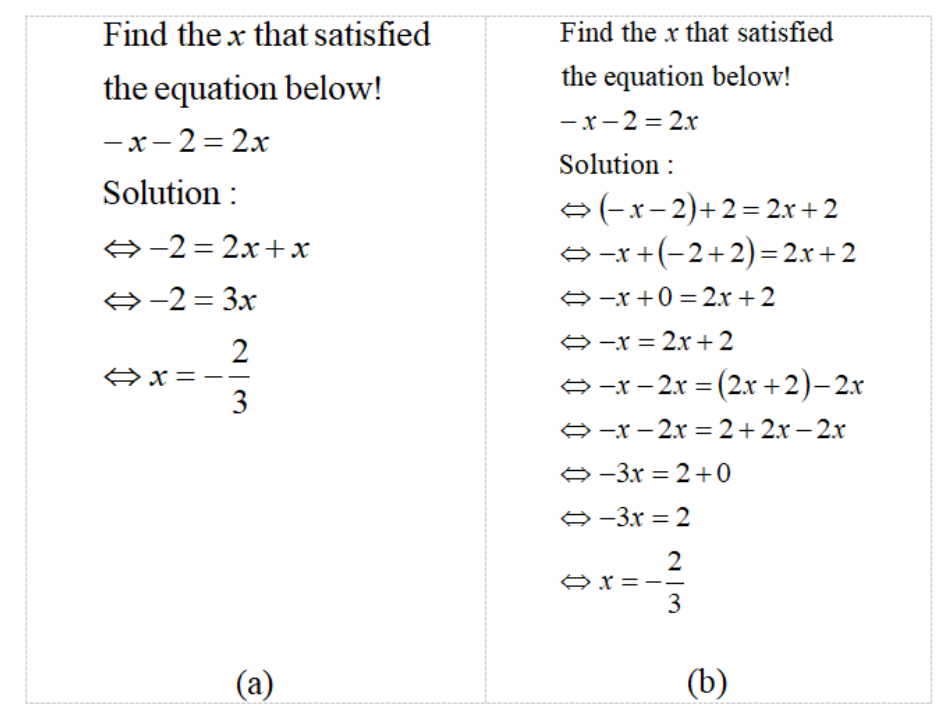

Fig. 1. A sample of exercises: (a) in the conventional textbook (b) in the textbook that developed.

One component of algebra, linear equation solving, is considered a basic skill by many in mathematics education and is recommended as a curriculum focal point for Grade 7 by the National Council of Teachers of Mathematics [10]. Fig. 1(a) is an example of exercises and its solution in the conventional textbook and Fig. 1(b) is an example of exercises and its solution in the textbook developed. It can be understood that in Fig. 1(a) the solution was using an incomplete algorithm. This means that students are considered to hold the basic algorithm to solve a linear equation while the characters of mathematics education students in UST have not been able to hold the algorithm so that sometimes the exercises makes students not understand the basic concept of solving a linear equation. Fig. 1(b) provides an overview of exercise with complete solutions. That means algorithm is explained clearly using existing theorems and definitions. This makes students to understand the basic concepts of solving linear equations.

Some exercises in the textbook are given with solutions that are complemented by explanations from each step of the solution. The explanation includes the interpretation of the theorems and axioms related to the steps of the solution. One example can be seen in Fig. 2.

Why is that important? Because of the characteristics of UST students who have not been able to adapt at the university's mathematics learning level, especially for the first semester 
students who are the object of research. For example in another textbook, students are given exercise as shown in Fig. 3. The exercise actually constructs students' thinking skills, but the characteristics of UST students who are not accustomed to critical thinking will make it difficult for students to accept the concepts given. In the end, when students were asked to explain the basic concepts for solving the problem, students were unable to explain and only make a solution without knowing the concept underlying the solution.

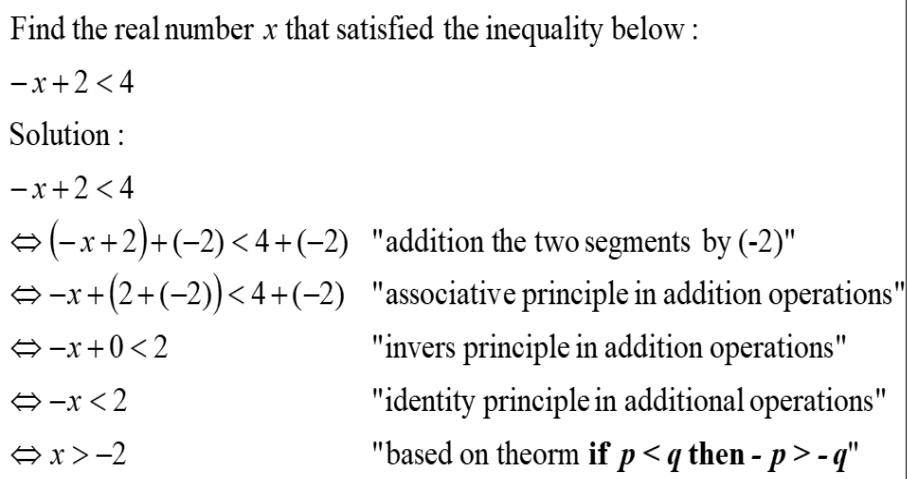

Fig. 2. A sample of exercises with explanations from each step.

Example: Find the solution set of $(x / 3)-2<4$.

$$
\frac{x}{3}+-2<4 . \quad \text { Why? }
$$

Add 2 to both members.

$$
\begin{array}{rlr}
\left(\frac{x}{3}+-2\right)+2 & <4+2 & \\
\frac{x}{3}+(-2+2) & <6 & \text { Why? } \\
\frac{x}{3}<6 & \text { Why? }
\end{array}
$$

Fig. 3. A sample of exercises in another textbook.

Fig. 3 interpret the solution of the exercises that focus on the reasoning ability of students. Sometimes this is very effective, but some factors can effected the purpose of the explanation of the solution described in Fig. 3. One of these factors is the lack of habituation of the mindset of students to reason.

In addition to the examples of exercises that have been explained previously, the textbook that developed also give exercises that adapted from the International Mathematics Olympiad. One example of this problem can be seen in Fig. 4. An exercise that is given in Fig. 4 is one of the International Mathematics Olympiad questions held in China [11] The exercise categorized medium level but if you observed, the solution given is too short and does not clarify every step 
of the solution. In the developed textbook, the problem is presented with as clear a solution as possible including the theorem used in solving the problem. More details can be seen in Fig. 5.

The solution set of the inequality $|x|^{3}-2 x^{2}-4|x|+3<0$ is

Solution Notice that $|x|=3$ is a root of the equation $|x|^{3}-2 x^{2}-$ $4|x|+3=0$. Then the original inequality can be rewritten as $(|x|-$ 3) $\left(|x|^{2}+|x|-1\right)<0$, that is

$$
(|x|-3)\left(|x|-\frac{-1+\sqrt{5}}{2}\right)\left(|x|-\frac{-1-\sqrt{5}}{2}\right)<0 .
$$

Since $|x|-\frac{-1-\sqrt{5}}{2}>0$, then $\frac{-1+\sqrt{5}}{2}<|x|<3$.

So the solution set is $\left(-3,-\frac{\sqrt{5}-1}{2}\right) \cup\left(\frac{\sqrt{5}-1}{2}, 3\right)$.

Fig. 4. Example of a question and the answer adapted from International Mathematics Olympiad.

Question: The solution set of the inequality $|x|^{3}-2 x^{2}-4|x|+3<0$ is

Solution :

Notice that $|x|=3$ is a root of the equation $|x|^{3}-2 x^{2}-4|x|+3=0$ [remember : if $x^{3}+b x^{2}+c x+d=0$ then roots of the equation are factors of $\left.d\right]$.

Then the original inequality can be rewritten as $(|x|-3)\left(|x|^{2}+|x|-1\right)<0$ that is

$(|x|-3)\left(|x|^{2}+|x|-1\right)<0$

$\Leftrightarrow(|x|-3)\left(|x|-\frac{-1-\sqrt{5}}{2}\right)\left(|x|-\frac{-1+\sqrt{5}}{2}\right)<0 \quad$ [remember : $a b c$ formula]

there are three cases that can be identified from the inequality, such as :

1) if $\left(|x|-\frac{-1+\sqrt{5}}{2}\right)>0$ then $(|x|-3)\left(|x|-\frac{-1-\sqrt{5}}{2}\right)<0$

2) if $\left(|x|-\frac{-1-\sqrt{5}}{2}\right)>0$ then $(|x|-3)\left(|x|-\frac{-1+\sqrt{5}}{2}\right)<0$

3) if $(|x|-3)>0$ then $\left(|x|-\frac{-1-\sqrt{5}}{2}\right)\left(|x|-\frac{-1+\sqrt{5}}{2}\right)<0$

Based on the cases, obtain :

$\frac{-1+\sqrt{5}}{2}<|x|<3$ [used the principle of the sequence of real numbers to finish it]

So the solution set is $\left(-3,-\frac{\sqrt{5}-1}{2}\right) \cup\left(\frac{\sqrt{5}-1}{2}, 3\right)$

Fig. 5. Example of a question and the answer adapted from International Mathematics Olympiad in the textbook that developed. 
The solution is given in Fig. 5 can be said to be more clear because it provides some steps that were not presented at the solution in Fig. 4. This is expected to make students better understand how to solve International Mathematical Olympiad questions related to algebra. In Fig. 5 it is mentioned $A B C$ formula which is one of the concepts to determine the root of the quadratic equation. $A B C$ formulas are obtained by reducing some algebraic properties. Sometimes students only know how to apply the $A B C$ formula without knowing the base concept of $A B C$ formula itself. Therefore, the developed textbook describes how to find the $A B C$ formula by reducing some algebraic properties. More details can be seen in Fig. 6 (a).

Another concept presented in the developed textbook is the symmetrical axis of the quadratic function. The quadratic function graph is a parabola. Therefore, in explaining the concept of a symmetrical axis the quadratic function must involve a parabola. The explanation will be more helpful because it can provide opportunities for students to remember the discussion about parabola. Proof that accompanied by a graph will help students understand the discussions. The majority of the extant studies look mainly at interpretation tasks [12], [13], [14], [15], [16], [17], [18], [19], [20], [21]. Interpretation we refer to the action by which a student makes sense or gains meaning from a graph (or a portion of a graph), a functional equation, or a situation. The proof of the symmetrical axis of the quadratic function can be seen in Fig. 6 (b). 


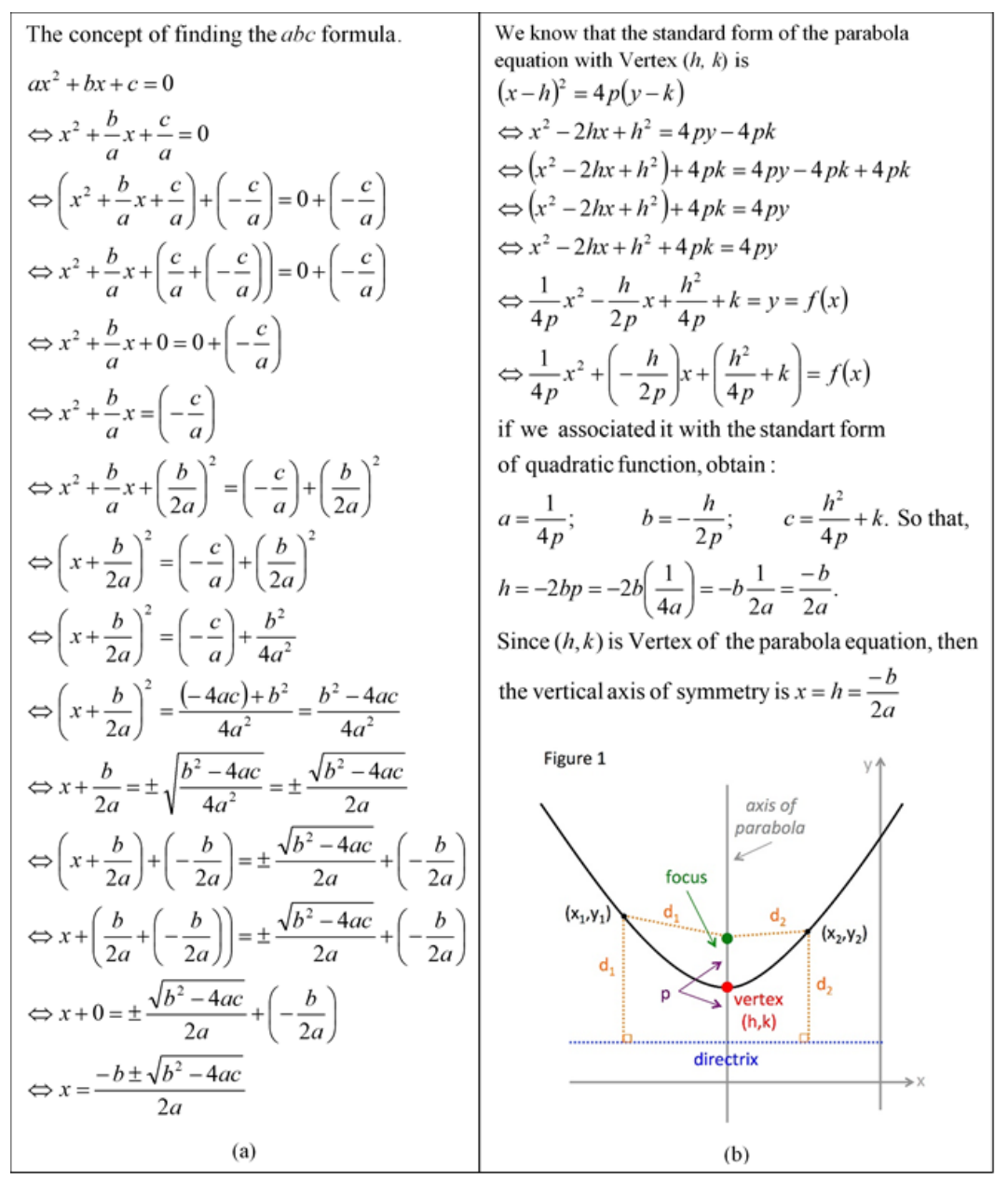

Fig. 6. (a) the proof of $A B C$ formula; (b) the proof of the vertical axis of symmetry.

\subsection{The Validation Test}

The textbook developed has been validated by textbook and materials experts who are lecturers in Mathematics Education Department UST and UAD with a minimum academic position as an Expert Assistant. Validation results are as follows:

- Material Validation. Based on the stages of the research, this textbook has been validated by material experts. The results of material validation are the average score in the aspect of content feasibility is 4.50 , on the aspect of presentation feasibility was 4.7 , while in the aspect of language assessment was 4.62 so that the average of all components was 4.6 that categorized very good. The presentation feasibility aspect has the highest average score than other aspects while the aspect of content feasibility has the lowest average score. Based on the results of the validation, the discussions in the textbook is proper to use.

- Textbook Validation. The developed textbook has three aspects assessed by the experts. Of the three aspects, the average score of all components is 4.65 . The average score on 
the aspect of textbooks' size was 5.00, the textbook cover design aspect was 4.44 and the textbook content design aspect was 4.5 , and then all aspects are categorized very well. The highest average score on textbook size aspect, while the lowest average on the textbook cover design aspect. Based on the results of the validation, it can be concluded the mathematical computation in the textbook is proper to use.

- Expert Comments. Comments of the experts can be seen in Table 1.

Table 1. Expert Comments Overview.

\begin{tabular}{|c|c|c|}
\hline Number & Comments & Product Revision \\
\hline 1 & $\begin{array}{l}\text { The cover title needs to be detailed. Focus on } \\
\text { the discussion of the lessons such as computa- } \\
\text { tions, not Matlab }\end{array}$ & $\begin{array}{l}\text { The textbook cover is repaired according } \\
\text { to the expert recommendation }\end{array}$ \\
\hline 2 & Need to add more references & $\begin{array}{l}\text { Add references that are relevant to the } \\
\text { textbook and its discussions }\end{array}$ \\
\hline 3 & $\begin{array}{l}\text { The aims of the learning must be put down at } \\
\text { the beginning of the textbook before the discus- } \\
\text { sions }\end{array}$ & $\begin{array}{l}\text { The aims of the learning put down at the } \\
\text { beginning of the textbook before the } \\
\text { discussions }\end{array}$ \\
\hline 4 & $\begin{array}{l}\text { In the learning instructions, there are ambiguous } \\
\text { words. }\end{array}$ & $\begin{array}{l}\text { Ambiguous words in learning instructions } \\
\text { are improved for the better }\end{array}$ \\
\hline 5 & $\begin{array}{l}\text { there are any symbols or notations that not use } \\
\text { Equation }\end{array}$ & $\begin{array}{l}\text { The symbols or notations used in } \\
\text { textbooks are written with Equations }\end{array}$ \\
\hline 6 & There is a graph that less contrast & $\begin{array}{l}\text { Graphics that less contrast are improved } \\
\text { to better graphics }\end{array}$ \\
\hline
\end{tabular}

- Product Revision. Based on comments and suggestions from experts, the researcher has repaired the textbook, such as textbook cover improvements, adding relevant literature, improving learning objectives, improving learning instructions, improving how to write a symbol/notation, and improving colour chart that less contrast.

Furthermore, the revised textbook was re-consulted with the validator. The consultation gave results that the textbook developed were appropriate to be implemented in the classroom.

\section{Conclusion}

The results of this study are learning instruments is a textbook for algebra lessons. This textbook is feasible to use in learning that can be seen from the results of material validation and textbook validation was carried out by material experts and textbook experts. The average score for the material was 4.60 and categorized very well while the average score for textbooks is 4.65 and categorized very well too. In addition, after revising the textbook according to comments from experts it was found that the textbooks developed were suitable to be implemented in the classroom. Based on this study, can be concluded that the textbook which developed was proper to use in Algebra learning.

\section{Acknowledgment}

The author would like to thank the LP3M of UST who have contributed this research and thanks to the experts who have validated this algebra textbook. And thank you to family, 
friends and co-workers who have helped in the implementation this research. In addition, the researchers would like to thank the first semester students of Mathematics Education UST who were the subject of research. Hopefully this research can contribute to national education. 


\section{References}

[1] A. . Goldie, "Book reviews: rings and radicals," J. London Math. Soc., vol. 41(1), pp. 760-761, 1966.

[2] D. Schifter and C. T. Fosnot, Reconstructing mathematics education: stories of teachers meeting the challenge of reform. New York: Teachers College Press, 1993.

[3] D. L. Ball, "Research on teaching mathematics: making subject-matter knowledge part of the equation. In J. Brophy (Ed.)," Adv. Res. Teach., vol. 2, pp. 1-48, 1991.

[4] G. Leinhardt and D. A. Smith, "Expertise in mathematics instruction: subject matter knowledge,” J. Educ. Psychol., vol. 77(3), pp. 247-271, 1985.

[5] Stein, M. K. Baxter, J. A., and G. Leinhardt, "Subject-knowledge and elementary education: a case from functions and graphing," Am. Educ. Res. J., vol. 27, pp. 639663, 1990.

[6] Trisnaningrih, "Pengembangan bahan ajar untuk meningkatkan pemahaman materi mata kuliah demografi teknik," J. Ekon. dan Pendidik., vol. 4(2), pp. 1 - 13, 2007.

[7] J. M. Hall and M. K. Ponton, "Mathemat-ics self-efficacy of college freshmen," J. Dev. Educ., vol. 20 (3)., pp. 26-32, 2005.

[8] Sungkono, Pengembangan bahan ajar. Yogyakarta: UNY Press, 2003.

[9] Soenarto, Metodologi penelitian pengembangan untuk meningkatkan kualitas pembelajaran. Bali: Departemen Pendidikan Nasional, 2005.

[10] C. Ballheim, "Readers respond to what's basic"” 1999, p. 11.

[11] M. C. N. C. Team, Mathematical olympiad in China. Shanghai: East China Normal University Press, 2007.

[12] G. Barr, "Graphs gradients and intercepts," in Mathematics in School, 1980, pp. 5-6.

[13] A. Bell and C. Janvier, "The interpretation of graphs representing situations," in For the Learning of Mathematics, 1981, pp. 32-42.

[14] J. B. Bestgen, "Making and interpreting graphs and tables," in Teacher, Results and implications from national assessment. Arithmetic, 1980, pp. 26-29.

[15] J. Clement, "The concept of variation and misconceptions in Cartesian graphing," in Focus on Learning Problems in Mathematics, 1989, pp. 77-87. 
[16] T. Dreyfus and T. Eisenberg, "Intuitive functional concepts: a baseline study on intuitions,” J. fior Res. Math. Educ., vol. 13(5), pp. 360-380, 1982.

[17] C. Janvier, "Difficulties related to the concept of variables presented graphically. In C. Comiti (Ed.)," in Proceedings of the fifth international conference of the International Group of Psychology of Mathematics Education, 1981, pp. 189-193.

[18] H. Krabbendam, "The non-qualitative way of describing relations and the role of graphs: some experiments. In G.Van Barnveld \& H. Krabbendam (Eds.)," in Conference on fiuntlions, 1982, pp. 125-146.

[19] D. L. McKenzie and M. J. Padilla, "The construction and validation of the Test of Graphing in Science (TOGS)," J. Res. Sci. Teach., vol. 23(7), pp. 571-579, 1986.

[20] G. S. Monk, "Students' understanding of functions in calculus courses," Washington, 1987.

[21] S. Vinner, "Concept definition, concept image and the notion of function," Int. J. Math. Educ. Sci. Technol., vol. 14(3), pp. 293-305, 1983. 